UDC 631.46.631.445.41:631.84

(C) 2016

I. Malynovska, doctor of agricultural sciences

O. Chernysh

V. Yula, Candidate of Agricultural Sciences

National Scientific Center "Institute of Agriculture of NAAS"

\title{
SPECIMEN OF MULTIFUNCTIONAL ACTION FOR GROWING SPRING WHEAT
}

The purpose. Takeoff of efficient bacterial compositions on the basis of associative nitrogen-fixing microorganism Agrobacterium radiobacter and strains of phosphatemobilizing bacteria as a stage of creation of a new complex specimen of multifunctional action for cereals - Agrobacterin. Methods. Laboratoryanalytical, microbiological, experimentally-field, statistical. Results. 5-years data concerning productivity of spring wheat are generalized at processing of treated and non-treated grain with Vitavax by bacterial compositions in alternatives with importation of nitrogenous artificial fertilizers into doses of N0, N30, N45. Conclusions. It is fixed that bacterization of the treated seeds of spring wheat promoted increase of productivity of plants at use of the following compositions: $A$. Radiobacter $+B$. Subtilis 100, A. radiobacter $+B$. Pumilis $M$, A. radiobacter $+B$. mucilaginosus, $A$. radiobacter + polystrain $B$. subtilis. At processing non-treated seeds the best compositions are the following: A. Radiobacter $+B$. subtilis 33, A. Radiobacter $+B$. mucilaginosus, $A$. radiobacter + polystrain $B$. subtilis. Use of that mixes without importation of nitrogen fertilizers promotes increase of productivity for $27,2 \%, 17,3$ and 29,6\% accordingly.

Key words: bacterization, nitrogen-fixing ability, phosphatemobilization, polystrain, artificial fertilizers, treated grain, productivity, yield.

At the current stage introduction in production of energy efficient technologies using environmentally friendly bacterial preparations based on mixed cultures diazotrofiv assists an increase yield and grain quality of spring crops [1-5]. During 15 years in the NSC "Institute of Agriculture NAAS" is working to create a new integrated preparation for cereals "Ahrobakteryn" which is composite and includes strain Agrobacterium radiobacter, and one or more strains of soil phosphate immobilizing microbes can converts soluble compounds phosphorus available to plants form. Conducted laboratory and field studies have shown that the bacterial composition intensify plant growth and development through the production of biologically active substances and substances from regulatory functions, reduce the incidence of plant 
bacterial and fungal diseases through selection of strains with high antagonistic properties, in crease plant resistancetobiotic and abiotic stressors, change the composition of rhizosphere microbial communities [6]. The application of "Ahrobakteryn" allows saving nitrogen and phosphate fertilizers at 25 - $45 \mathrm{~kg} / \mathrm{ha}$ of active substance.

The purpose - the selection of effective bacterial compositions based on associative nitrogen-fixing microorganisms Agrobacterium radiobacter and strains of soil phosphate immobilizing microbes as a stage of creation of a new complex preparation of multifunctional action for cereal crops "Agrobacterin".

Materials and methods of research. In temporary experiment (2007-2010) in the department of adaptive technology intensive cereals and maize (NSC "Institute of Agriculture NAAS") features of formation of productivity of spring wheat varieties Early 93 depending on the use of bacterial compositions have studied. Soil of experiment plot - dark gray ashed krupnopyluvatyy on loess loam, which is characterized by the following agrochemical indexes: nitrogen - 7.80, phosphorus $\left(\mathrm{P}_{2} \mathrm{O}_{5}\right)$ - 17.6, potassium $\left(\mathrm{K}_{2} \mathrm{O}\right)-12.5 \mathrm{mg} / 100$ g soil. Seeding rate of wheat was 5 million of similar seeds per 1 ha. Methods of treatment of bacterial compositions seeds - common [7,8]. The strains of soil phosphate immobilizing microbes and nitrogen-fixing strain of A. radiobacter 10 we used for seed treatment [9-11]. The correlation of the number of bacteria of soil nitrogen-fixing and phosphate immobilizing strains was 1:1 in bacterial mixture. The total bacterial load was 200000 cells/seed. Experiments were performed using seeds that were treated and not treated with the "Vitavaks" at a dose of 3,0 liters per 1 ton of seeds. Growth and development of wheat plants studied by introducing different doses of nitrogen fertilizers: $\mathrm{N}_{0}, \mathrm{~N}_{30}, \mathrm{~N}_{45}$. The area of register plot is $10 \mathrm{~m}^{2}$, repeatedness - quadruple. Agrotechnics of growing - generally accepted for a zone.

Statistical analysis of the results was carried out using modern software Microsoft Excel. 
Results. The bacterial treatment of wheat seeds (without "Vitavaks" of use) can affect the number of spikelets and grains of the main ear (Table 1).These indicators are increased in versions treatment compositions A. radiobacter $+B$. subtilis 33, A. radiobacter + B. mucilaginosus, A. radiobacter + polistrain B. subtilis by treatment all doses of nitrogen fertilizers. Increasing the number of spikelets in accordance doses of fertilizers were $8,33 \% ; 4,90 ; 5,28 \%$ of the main spikelet and $12,8 \% ; 10,7 \%$ and 26,2 the number of grains of the main spikelet. Without optimization of power plants with nitrogen is effective monotreatment associative nitrogen fixation A.radiobacter.

On condition processing of seeds (the use "Vitavaks") was increased number of spikelets and grains of the main spikelet in almost all variants with bakteryzation The bacterial treatment compositions A. radiobacter + B. subtilis 100 and B. mucilaginosus increased number of spikelets on 7,9\% (without nitrogen fertilizers) to $5,76 \%$ and $10,1 \%$ - (the use nitrogen fertilizer in doses $\mathrm{N}_{30}$ ).

Number of grains in a main spikelet without the use of nitrogen fertilizers increases versions A radiobacter $+B$. subtilis 100 and A. radiobacter + polistrain B. subtilis (22,1 and 13,4\%). When applying nitrogen fertilizer at a dose of $\mathrm{N}_{45}$ were effective composition A. radiobacter + B. subtilis 100 and A. radiobacter + B. mucilaginosus, which increase the number of grains of the main spikelet on 26,7 and $23,9 \%$ respectively. Established that bacterial treatment affects the productivity of individual plants of spring wheat (Table 2). For the treatment of seed (without "Vitavaks" of use) were the best compositions A radiobacter + B. subtilis 33,

1. Influence of complex bacterial treatment on the structures of the spikelet of wheat varieties Early 93, the average for 2007-2010.

\begin{tabular}{|c|c|c|c|c|c|c|}
\hline \multirow{3}{*}{ Variant of experiment } & \multicolumn{4}{|c|}{ The structure of the main spikelet } \\
\cline { 2 - 6 } & $\begin{array}{c}\text { number of spikelets in the } \\
\text { main spikelet }\end{array}$ & \multicolumn{2}{|c|}{$\begin{array}{c}\text { the number of grains of } \\
\text { the main spikelet }\end{array}$} \\
\cline { 2 - 7 } & $\begin{array}{c}\text { without } \\
\text { applying } \\
\text { of N }\end{array}$ & $\begin{array}{c}\text { applying } \\
\text { of N30 }\end{array}$ & $\begin{array}{c}\text { applying } \\
\text { of N45 }\end{array}$ & $\begin{array}{c}\text { without } \\
\text { applying } \\
\text { of N }\end{array}$ & $\begin{array}{c}\text { apply- } \\
\text { ing of } \\
\mathrm{N}_{30}\end{array}$ & $\begin{array}{c}\text { apply- } \\
\text { ing of } \\
\mathrm{N}_{45}\end{array}$ \\
\hline
\end{tabular}




\begin{tabular}{|c|c|c|c|c|c|c|}
\hline \multicolumn{7}{|c|}{ Without "Vitavaks" of use } \\
\hline $\begin{array}{l}\text { 1. Control (treatment of } \\
\text { water) }\end{array}$ & 13,6 & 13,6 & 13,9 & 29,7 & 30,1 & 30,9 \\
\hline 2. A. radiobacter & 15,0 & 13,8 & 14,5 & 33,0 & 31,0 & 32,8 \\
\hline $\begin{array}{l}\text { 3. A. radiobacter }+B \text {. } \\
\text { subtilis } 33\end{array}$ & 14,7 & 14,3 & 14,7 & 32,9 & 34,0 & 34,6 \\
\hline $\begin{array}{l}\text { 4. A. radiobacter }+B \text {. } \\
\text { subtilis } 100\end{array}$ & 14,0 & 14,1 & 14,2 & 31,4 & 33,1 & 31,7 \\
\hline $\begin{array}{l}\text { 5. A. radiobacter }+B \text {. } \\
\text { pumilis } M\end{array}$ & 14,0 & 13,8 & 14,1 & 31,4 & 31,4 & 33,1 \\
\hline $\begin{array}{l}\text { 6. A. radiobacter }+B \text {. } \\
\text { mucilaginosus }\end{array}$ & 14,6 & 14,1 & 14,5 & 33,6 & 33,2 & 32,9 \\
\hline $\begin{array}{l}\text { 7. A. radiobacter }+ \\
\text { polistrain } B \text {. subtilis }\end{array}$ & 14,9 & 14,4 & 14,7 & 34,0 & 32,8 & 33,3 \\
\hline $\mathrm{LMI}_{05}$ & 0,30 & 0,30 & 0,31 & 1,20 & 0,90 & 0,98 \\
\hline \multicolumn{7}{|c|}{ The use "Vitavaks" } \\
\hline $\begin{array}{l}\text { 1. Control (treatment of } \\
\text { water) }\end{array}$ & 13,9 & 13,9 & 14,3 & 30,7 & 30,8 & 31,8 \\
\hline 2. A. radiobacter & 14,5 & 13,8 & 14,7 & 33,0 & 30,3 & 34,5 \\
\hline $\begin{array}{l}\text { 3. A. radiobacter }+B \text {. } \\
\text { subtilis } 33\end{array}$ & 14,5 & 14,8 & 14,9 & 33,5 & 33,1 & 35,2 \\
\hline $\begin{array}{l}\text { 4. A. radiobacter }+B . \\
\text { subtilis } 100\end{array}$ & 15,0 & 14,7 & 15,1 & 37,5 & 33,6 & 40,3 \\
\hline $\begin{array}{l}\text { 5. A. radiobacter }+B \text {. } \\
\text { pumilis } M\end{array}$ & 14,6 & 14,3 & 14,1 & 32,9 & 34,2 & 35,5 \\
\hline $\begin{array}{l}\text { 6. A. radiobacter }+B \text {. } \\
\text { mucilaginosus }\end{array}$ & 15,0 & 15,3 & 15,3 & 33,2 & 33,1 & 39,4 \\
\hline $\begin{array}{l}\text { 7. A. radiobacter }+ \\
\text { polistrain } B \text {. subtilis }\end{array}$ & 14,8 & 14,4 & 14,8 & 34,8 & 32,7 & 35,3 \\
\hline $\mathrm{LMI}_{05}$ & 0,40 & 0,29 & 0,30 & 1,00 & 0,85 & 1,15 \\
\hline
\end{tabular}

A. radiobacter + B. mucilaginosus, A radiobacter + polistrain B. subtilis and 
monotreatment $A$. radiobacter. Bakteryzation them in the background without the use of nitrogen fertilizers increased the grain weight per plant on 17,3; 27,2, 17,3 and $29,6 \%$ respectively. With the use of nitrogen fertilizers in a dose of $\mathrm{N}_{30}$ in the list of compositions added effective composition A radiobacter $+B$. pumilis $M$.

The bakteryzation of seeds was effective. The greatest increase in productivity was the use of fertilizers in doses of $\mathrm{N}_{45}$. The maximum productivity of plants on background without of nitrogen fertilizer observed for processing A. radiobacter + polistrain B. subtilis - 43,4\%, with the introduction of nitrogen fertilizers in doses $N_{30}$ - A. radiobacter $+B$. pumilis $M(34,1 \%)$, with the introduction of nitrogen fertilizers in doses $\mathrm{N}_{45}-$ A. radiobacter + B. subtilis $100(12,4 \%)$.

The treatment of bacterial compositions seed spring wheat varieties Early 93 contributed to increasing yields. In experiment (without "Vitavaks" of use, without the use of nitrogen fertilizer) the yield of wheat was increased by treatment of A. radiobacter $+B$. pumilis $M$, A. radiobacter $+B$. mucilaginosus, A. radiobacter + polistrain B. subtilis by 0,$45 ; 0,48$ and $0,41 \mathrm{t} /$ ha, respectively (Table. 3). The increased a yields in versions (the use "Vitavaks") by processing compositions noted A. radiobacter + B. subtilis 33 (on 0,34 t/ ha), A. radiobacter $+B$. mucilaginosus (on 0,51 t / ha), A. radiobacter + polistrain B. subtilis ( on 0,61 t / ha).

The increased yields is observed for processing a compositions $A$. radiobacter + B. pumilis $M$, A. radiobacter + B. mucilaginosus, A. radiobacter + polistrain B. subtilis variant as in the experiment using "Vitavaks" and experiment in the

2. Influence of complex bacterial treatment on the productivity of spring wheat varieties Early 93, average for 2007-2010 years.

\begin{tabular}{|c|c|c|c|c|c|c|}
\hline \multirow{3}{*}{ Variant of experiment } & \multicolumn{6}{|c|}{ Grain weight per 1 plant } \\
\hline & \multicolumn{3}{|c|}{ Without "Vitavaks" of use } & \multicolumn{3}{|c|}{ The use "Vitavaks" } \\
\hline & $\begin{array}{c}\text { without } \\
\text { applying } \\
\text { of } \mathrm{N}\end{array}$ & $\begin{array}{c}\text { applying } \\
\text { of } \mathrm{N}_{30}\end{array}$ & $\begin{array}{c}\text { applying } \\
\text { of } \mathrm{N}_{45}\end{array}$ & $\begin{array}{l}\text { without } \\
\text { applying } \\
\text { of } \mathrm{N}\end{array}$ & $\begin{array}{c}\text { applying } \\
\text { of } \mathrm{N}_{30}\end{array}$ & $\begin{array}{c}\text { applying } \\
\text { of } \mathrm{N}_{45}\end{array}$ \\
\hline
\end{tabular}




\begin{tabular}{|l|c|c|c|c|c|c|}
\hline $\begin{array}{l}\text { 1. Control (treatment of } \\
\text { water) }\end{array}$ & 0,81 & 0,89 & 0,97 & 0,83 & 0,88 & 1,05 \\
\hline $\begin{array}{l}\text { 2. A. radiobacter } \\
\text { 3. A. radiobacter + B. } \\
\text { subtilis 33 }\end{array}$ & 0,95 & 1,08 & 1,05 & 0,99 & 1,01 & 1,09 \\
\hline $\begin{array}{l}\text { 4. A. radiobacter + B. } \\
\text { subtilis } 100\end{array}$ & 0,92 & 0,99 & 0,97 & 1,08 & 1,10 & 1,18 \\
\hline $\begin{array}{l}\text { 5. A. radiobacter }+B . \\
\text { pumilis } M\end{array}$ & 0,92 & 1,04 & 0,97 & 1,07 & 1,18 & 1,12 \\
\hline $\begin{array}{l}\text { 6. A. radiobacter }+B . \\
\text { mucilaginosus }\end{array}$ & 1,03 & 1,10 & 1,05 & 1,12 & 1,05 & 1,15 \\
\hline $\begin{array}{l}\text { 7. A. radiobacter }+ \\
\text { polistrain } B . \text { subtilis }\end{array}$ & 0,95 & 1,04 & 1,09 & 1,19 & 1,06 & 1,32 \\
\hline LMI 05 & 0,12 & 0,11 & 0,07 & 0,07 & 0,08 & 0,08 \\
\hline
\end{tabular}

version without the use "Vitavaks" ( the use nitrogen fertilizer in doses $\mathrm{N}_{30}$ ) (Table.3). In an experiment without of use "Vitavaks" increase yields of bakteryzation was respectively 0,$40 ; 0,36$ and $0,44 \mathrm{t} / \mathrm{ha}$; in the version of the experiment using "Vitavaks" increase yields was respectively 0,52; 0.48 and 0,53 t / ha.

In the variant without the use "Vitavaks" effective were the compositions of A. radiobacter + B. subtilis 33, A. radiobacter + B. mucilaginosus, A. radiobacter + polistrain $B$. subtilis, the treatment which a contributed increase yields respectively 0,38; 0,55 and $0,49 \mathrm{t} / \mathrm{ha}$ (the introduction nitrogen fertilizer at a dose of $\mathrm{N}_{45}$ ) (Table.3). With the use of treated seeds (the use "Vitavaks") the effective were compositions comprising A. radiobacter + B. pumilis $M$, A. radiobacter + B. mucilaginosus, A. radiobacter + polistrain B. subtilis, increased yields on the 0,69; 0,58 and 0,71 t / ha, respectively. For long-years data, fertilization was effective and enabled yield gains in almost all studied bacterial compositions. The use "Vitavaks" also was effective and gave increase yields $0,11-0,18 \mathrm{t} /$ ha. So, for stimulation development of spring wheat plants, improving yield and quality of grain in foreststeppe zone proposed seed treatment before sowing the preparation action based 
multifunctional A. radiobacter and polistrain B. subtilis. This preparation has a complex agronomically valuable properties, namely high level of activity associative nitrogen fixation, produce of substances stimulating, fosfatmobilization and antibiotic action. The preparation can be used for processing of wheat seeds without the use "Vitavaks" and the use "Vitavaks", at different levels of availability of mineral nitrogen: no fertilizer, the use the $\mathrm{N}_{30}$ and $\mathrm{N}_{45}$. Wheat yields increased as a result bakteryzation of seeds on the nontreated and treated "Vitavaks" by 0,41 and 0,61 t / ha, respectively (without the use of nitrogen fertilizers). Wheat yields increased as a result bakteryzation of seeds on the nontreated and treated "Vitavaks" by 0,41 and $0,61 \mathrm{t} /$ ha respectively (without the use of nitrogen fertilizers). Wheat yields increased as a result bakteryzation of seeds on the nontreated and treated "Vitavaks" by 0,49 and $0,71 \mathrm{t} /$ ha respectively (the use nitrogen fertilizer in doses $\mathrm{N}_{45}$ ). The treatment of seed of bacterial preparation "Ahrobakteryn" will improve the environmental situation in agrocenoses by reducing the doses of mineral fertilizers and rejection of the use of "Vitavaks". 
3. Influence of complex treatment of bacterial yields of spring wheat varieties Early 93, the average for 2007-2010.

\begin{tabular}{|c|c|c|c|c|c|c|c|c|c|c|c|c|}
\hline \multirow{3}{*}{ Variant of experiment } & \multicolumn{6}{|c|}{ Without "Vitavaks" of use } & \multicolumn{6}{|c|}{ The use "Vitavaks" } \\
\hline & \multicolumn{2}{|c|}{$\mathrm{N}_{0}$} & \multicolumn{2}{|c|}{$\mathrm{N}_{30}$} & \multicolumn{2}{|c|}{$\mathrm{N}_{45}$} & \multicolumn{2}{|c|}{$\mathrm{N}_{0}$} & \multicolumn{2}{|c|}{$\mathrm{N}_{30}$} & \multicolumn{2}{|c|}{$\mathrm{N}_{45}$} \\
\hline & $\begin{array}{l}\text { Yield, } \\
\text { t / ha }\end{array}$ & $\begin{array}{l}\text { Incre- } \\
\text { ase, } \\
\mathrm{t} / \mathrm{ha}\end{array}$ & $\begin{array}{l}\text { Yield, } \\
\text { t / ha }\end{array}$ & $\begin{array}{l}\text { Incre- } \\
\text { ase, } \\
\text { t / ha }\end{array}$ & $\begin{array}{l}\text { Yield, } \\
\text { t / ha }\end{array}$ & $\begin{array}{l}\text { Incre- } \\
\text { ase, } \\
\text { t / ha }\end{array}$ & $\begin{array}{l}\text { Yield, } \\
\text { t / ha }\end{array}$ & $\begin{array}{l}\text { Incre- } \\
\text { ase, } \\
\text { t / ha }\end{array}$ & $\begin{array}{l}\text { Yield, } \\
\text { t / ha }\end{array}$ & $\begin{array}{l}\text { Incre- } \\
\text { ase, } \\
\text { t / ha }\end{array}$ & $\begin{array}{l}\text { Yield, } \\
\text { t / ha }\end{array}$ & $\begin{array}{l}\text { Incre- } \\
\text { ase, } \\
\text { t / ha }\end{array}$ \\
\hline $\begin{array}{l}\text { 1. Control (treatment } \\
\text { of water) }\end{array}$ & 2,15 & - & 2,28 & - & 2,33 & - & 2,39 & - & 2,38 & - & 2,44 & - \\
\hline 2. A. radiobacter & 2,42 & 0,27 & 2,27 & - & 2,50 & 0,17 & 2,30 & - & 2,63 & 0,25 & 2,75 & 0,31 \\
\hline $\begin{array}{l}\text { 3. A. radiobacter }+B \text {. } \\
\text { subtilis } 33\end{array}$ & 2,46 & 0,31 & 2,60 & 0,32 & 2,71 & 0,38 & 2,73 & 0,34 & 2,71 & 0,33 & 2,77 & 0,33 \\
\hline $\begin{array}{l}\text { 6. A. radiobacter }+B \text {. } \\
\text { mucilaginosus }\end{array}$ & 2,63 & 0.48 & 2,64 & 0,36 & 2,88 & 0,55 & 2,90 & 0,51 & 2,86 & 0,48 & 3,02 & 0,58 \\
\hline $\begin{array}{l}\text { 7. A. radiobacter }+ \\
\text { polistrain } B \text {. subtilis }\end{array}$ & 2,56 & 0,41 & 2,72 & 0,44 & 2,82 & 0,49 & 3,00 & 0,61 & 2,91 & 0,53 & 3,15 & 0,71 \\
\hline $\mathrm{LMI}_{05}$ & 0,12 & & 0,32 & & 0,22 & & 0,15 & & 0,12 & & 0,12 & \\
\hline
\end{tabular}




\section{Conclusions.}

1. Bacterization seed spring wheat varieties Early 93 (the use "Vitavaks") to increase plant productivity by using compositions $A$. radiobacter $+B$. subtilis 100, A. radiobacter $+B$. pumilis $M$, A. radiobacter $+B$. mucilaginosus, A.radiobacter + polistrain B. subtilis.

2. Bacterial seed treatment (without "Vitavaks") promoted the increase grain weight per 1 plant of $17.3,27.2,17.3$ and $29.6 \%$ by the use of $A$. radiobacter +

B. subtilis 33, A. radiobacter + B. mucilaginosus, A. radiobacter + polistrain B. subtilis and treatment only A. radiobacter respectively (without introduction nitrogen fertilizers).

3. The composition A. radiobacter + polistrain B. subtilis is recommended to use as the basis for bacterial preparation for spring wheat. Spring wheat yield increases with bakteryzation the nontreated and treated "Vitavaks" seeds by 0.41 and $0.61 \mathrm{t} / \mathrm{ha}$ respectively (without introduction nitrogen fertilizers); at 0.44 and $0.53 \mathrm{t} /$ ha respectively (introduction of nitrogen fertilizers in doses $\mathrm{N} 30$ ); at 0.49 and $0.71 \mathrm{t} /$ ha respectively (introduction of nitrogen fertilizers in doses N45).

\section{Bibliography}

1. Kołodziejczyk M. Effect of nitrogen fertilization and application of soil properties improving microbial preparations on the content of mineral nitrogen in soil after spring wheat harvesting/M. Kołodziejczyk//J. of Central European Agriculture. 2013. - 14(1). - P. $306-318$.

2. Sharkova S.Yu. Urozhaynost' zerna pshenytsы pry ynokulyatsyy ryzoahrynom/S.Yu. Sharkova//Materyalы nauch.-prakt. konf., posvyashch. 75-letyyu so dnya rozhdenyya prof. H.B. Hal'dyna (1928 - 1994), 25 - 26 noyab. 2003 h. Penza: FHOU VPO «Penzen. HSKhA», 2003. - S. 176 - 178.

3. Volkohon V.V. Mikrobni preparaty yak faktor pidvyshchennya zasvoyuvanosti roslynamy mineral'nykh dobryv/V.V. Volkohon//Sil's'kohospodars'ka mikrobiolohiya. - 2006. - Vyp. 4. - S. 21 - 34. 
4. Nadkrenychna O.V. Mikrobnyy preparat Diazobakteryn — vahomyy chynnyk efektyvnosti vyrobnytstva ozymoho zhyta/O.V. Nadkrenychna, Yu.M.

Khalep//Chernihivshchyna ahrarna. - 2013. - № 23. - S. 29 - 30.

5. Metodolohiya i praktyka vykorystannya mikrobnykh preparativ u tekhnolohiyakh vyroshchuvannya sil's'kohospodars'kykh kul'tur/V.V. Volkohon, A.S. Zaryshnyak, I.V. Hrynyk ta in.; za red. V.V. Volkohona. — K.: Ahrar. nauka, 2011. — 156 s. 6. Malynovs'ka I.M. Vplyv kompleksnoyi obrobky Agrobacterium radiobacter ta fosformobilizivnymy mikroorhanizmamy na vrozhaynist' yaroyi pshenytsi/I.M. Malynovs'ka, O.O. Chernysh//Alelopatiya ta azotfiksatsiya v ahroekosystemakh: mater. nauk.-prak. konf., 15 - 16 lystop. 2007 r. — Kh., 2007. — S. 101 - 102. 7. Patyka V.P. Rekomendatsiyi po efektyvnomu zastosuvannyu mikrobiolohichnykh preparativ u suchasnomu resursozberihayuchomu zemlerobstvi/V.P. Patyka, O.V. Sherstoboyeva. - Chernihiv: In-t s.-h. mikrobiol., 1999. - 22 s. 8. Rekomendatsiyi z efektyvnoho zastosuvannya mikrobnykh preparativ u tekhnolohiyakh vyroshchuvannya sil's'kohospodars'kykh kul'tur/S.I. Mel'nyk, V.A. Zhylkin, M.M. Havrylyuk ta in. - K., 2007. — 53 s.

9. Smyrnov V.V. Bakteryy roda Bacillus - perspektyvnыy ystochnyk byolohychesky aktyvnыkh veshchestv/V.V. Smyrnov//Mikrobiol. zhurn. — 2001. — T. 63, № 1. S. $72-79$.

10. Nomer hosudarstvennoy rehystratsyy 0747-07-203-230-0-0-0-0, cvydetel'stvo № 0747 ot 25.04.2007.

11. Sertyfykat sootvetstvyya № ROSS RU.MH08. N25242 ot 02.02.2015 h. ; эkolohycheskyy sertyfykat sootvet·stvyya SER (2048)-H-311/OS-51 ot 10.06.2013 h. 